\title{
DYEING OF WOOLEN FIBERS WITH RHODODENDRON ARBOREUM FLOWERS USING SYMPLOCOS RACEMOSA LEAVES AS MORDANT UNDER OPTIMUM CONDITIONS
}

\author{
Pranjali Purohit $^{1}$, Mahesh Chandra Purohit ${ }^{2 *}$, Anuj Kandwal ${ }^{2}$ and Rashmi Rawat ${ }^{2}$ \\ ${ }^{I}$ Department of Chemistry, Graphic Era University, Dehradun, Uttarakhand, India \\ ${ }^{2}$ Department of Chemistry, HNB Garhwal University, BGR Campus Pauri, (Garhwal) 246001, \\ Uttarakhand, India
}

*Corresponding Author Email id: mcpurohit123@gmail.com

Received: 10.10.2020; Revised: 11.11.2020; Accepted: 15.11.2020

CSociety for Himalayan Action Research and Development

\begin{abstract}
Out of the multiple applications of the diverse natural products of Uttarakhand dyeing of fabrics with the help of various plant parts has always stood out. In the present investigation, an attempt has been made to extract natural dye from Rhododendron arboretum flowers and to optimize conditions of concentration and time for dyeing woolen sample from the extracted dye. The results showed that the colour strength (\% Absorbance) increases with the increase in concentration of dye up to $0.03 \mathrm{~g} / \mathrm{ml}$ concentration. Also, dyeing procedure has been optimized by using Symplocos racemosa leaves as mordant. The best results were obtained using simultaneous mordanting method with Symplocos racemosa leaves at $0.03 \mathrm{~g} / \mathrm{ml}$ concentration.
\end{abstract}

Keywords: Natural dye, Rhododendron arboreum, Absorbance, Symplocos racemosa, Natural mordant.

\section{Introduction}

The co-existence of humanity and colours dates back to the advent of human civilization itself. Apart from this, colour was used on the walls of caves, baskets and many other items of dayto-day use (Gulrajani, 2001). Across the globe some specific plants and animals have been used as sources of specific colours like red, yellow, blue and black (Gulrajani, 1999; Gulrajani, et al., 2003; Mukherji, 1999). Various researchers have reported important natural dyes holding promise for the future (Naz and Bhatti, 2011; Samantha and Agarwal, 2007; Gulrajani and Deepti 2011; Singh and Kalirajan 2012). Natural dyes and mordants made from flora and fauna are considered to be safe due to their non-toxic, noncarcinogenic and biodegradable nature (Geetha and Sumathy 2013; Han and Yang 2005; Khan et al., 2012). The hill state of Uttarakhand also shows ample references of dyeing with indigenous plant species which are mainly confined to the native Bhotiya and Shauka tribes of high altitudes of the border districts of Pithoragarh, Chamoli and Uttarkashi. It was Atkinson in 1882 who for the first time gave a systematic list of the dyeyielding plants of Uttarakhand (Atkinson, 1882; Negi, 2006). The old manuscripts got their name 'Pandulipi'from yellow colour $($ Pandu $=$ yellow $)$ itself. Scholars like Gaur, (2008) and Sharma et al., (2012) have given a detailed list of the dyeyielding plants of Uttarakhand. Kundal \& Purohit (2014) optimize some new dyeing procedure on cotton and wool fibers. Purohit et.al (2018) explore some plants leaves as a source of natural dye as well as natural mordants.

Rhododendron arboretum is one of the prominent species of the genus Rhododendron. The plant bears graceful flowers in the months of March-April which show a great variety in 
colour ranging from a deep scarlet to red with white markings, crimson to pale pink or white (Gaur, 1999). The flowers are showy, red in dense globose, cymes (Chauhan, 1999). The dried flowers of $R$. arboretum are supposed to be highly efficient in checking diarrhoea and blood dysentery (Lalooet al., 2006). The flowers which are sweet and sour in taste are used in preparing squash, jam, jellies and local brew. The acidsweet fresh and dried corolla is prescribed when fish bones get struck in the gullet (Pradhan and Lachungpa, 1990). Recently dye from the flowers of $R$. arboretum has been reported by Purohit et al., (2008). Symplocos racemosa roxb.is an important member of the family Symplocaceae with vital medicinal applications.Talking of its dyeing application, in Indo-China, Symplocos racemosa roxb. is used as a mordant while in India its leaves and bark are used to prepare a yellow dye. Purohit et al., (2015) have reported the leaves of Symplocos racemosa as a source of mordant. Use of leaves of the plant as mordant in combination with lemon juice has also been reported (Joshi et al., 2013). Colour fastness properties of dye extracted from Symplocos species have been evaluated on wool fibers (Singh and Purohit, 2018).

Keeping in mind the need of reviving natural dyes so as to be environment-friendly the present study was undertaken which shows the use of Rhododendron arboreum flowers as natural dyes for dyeing woolen fiber. The shade produced was enhanced by employing Symplocos racemosa leaves as natural mordant. The entire process was optimized as well.

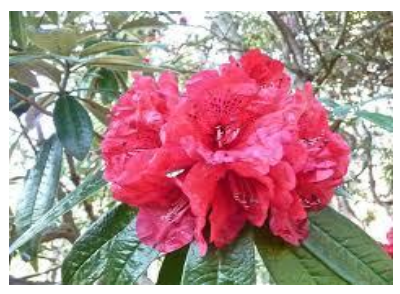

Figure 1 a) Rhododendron arboretum

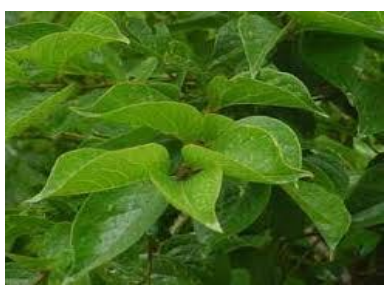

Figure 1(b) Symplocos racemosa

\section{Materials and methods}

Collection of plant material: The flowers of Rhododendron arboreum were collected in early April from the hills of Khandyusain, Pauri (1700m) while the collection of Symplocos racemosa leaves was done from Phalati (Mandakini Valley), Rudraprayag at the elevation of $1100 \mathrm{~m}$.

Textile Preparation for Dyeing: Wool has been taken as the dyeing fibre for the present study. To avoid tangling and to allow even penetration of the dye into the fabric the skein of wool was made by wounding around the arm from the hand and over the elbow. The skein was then soaked in the tap water for about $12 \mathrm{~h}$ to get rid of the water soluble impurities and finally it was scoured by cleaning with hot water and neutral soap. Scouring also allows uniform dyeing and removes the grease - 'lanolin' from the fibre.

Determination of Rate of Exhaustion or Percentage Absorbance: The O.Ds (Optical Densities) or \% Absorbances of the dye bath before and after dyeing were determined with the help of the UV-Visible Shimadzu spectrophotometer (Model UV-1601). Distilled water was used as the blank to calibrate the instrument to zero absorbance in each case and the wavelength was set to the maximum wavelength (i.e. wavelength of maximum absorbance $\lambda_{\max }$ ) of the dye used at that point.

The Rate of Exhaustion or Percentage Absorbance was calculated as follows:

Rate of Exhaustion $(\%)=(\mathrm{D} 1-\mathrm{D} 2) / \mathrm{D} 1 * 100$

Where $\mathrm{D} 1=$ O.D. before dyeing; D2 = O.D. after dyeing;

D1-D2 = amount of dye transferred into the fabric after dyeing.

\section{Optimization of Dyeing Procedure:}

For the present study, three parameters were taken into consideration- 
(1) Optimum concentration of dye: After soaking $10 \mathrm{~g}$ of $R$. arboretum flowers in varying volumes of hot water $(200 \mathrm{ml}, 400$ $\mathrm{ml}$ and $600 \mathrm{ml}$ each for $1 \mathrm{~h}$ ) and heating for a fixed time period $(30 \mathrm{~min})$ the solution was filtered and Optical Density (O.D.) of the filtrate was measured. Then the woolen fiber was dipped in the solution for $30 \mathrm{~min}$ (Dyeing time $=30 \mathrm{~min}$ ), taken out of the solution, squeezed and spread to dry followed by the measurement of the O.D. of the remaining solution. Percentage absorbance or rate of exhaustion was derived in each case with the help of the given formula. The concentration of dye corresponding to maximum percentage absorbance was finalized as the optimum concentration for each sample.

(2) Optimum time: The wool samples of optimum concentration (as determined in the previous step) were heated for $15,30,45$ and 60 minutes each and filtered. The O.D. of the filtrate was determined in each case. Thereafter, the woolen fibre was soaked in the solution for $30 \mathrm{~min}$, taken out, squeezed and spread to dry. Then the O.D. of the left solution was determined and percentage absorbance or rate of exhaustion was derived in each case. The value of time corresponding to maximum percentage absorbance corresponded to the optimum time for each sample.

(3) Mordanting method: After getting the optimum concentration and time of the dye, the woolen fabric was subjected to all the three types of mordanting (Pre-, Post- and Simultaneous).

Pre-mordanting: The fiber was first dipped and heated for $10 \mathrm{~min}$ in the mordant solution and then dipped in the dye solution and heated further for another $10 \mathrm{~min}$. It was then taken out and spread to dry. The O.D was measured before and after dyeing.

Post-mordanting: The fiber was first soaked and heated in the dye solution and then in an equal volume of mordant solution for $10 \mathrm{~min}$ each. It was then taken out and spread to dry.
The O.D. was determined before and after dyeing.

Simultaneous mordanting: Equal volumes of the dye and mordant solutions were mixed together and the fiber was dipped in this. The solution was heated for $20 \mathrm{~min}$. The fiber was taken out and spread to dry. O.D. was measured before and after dyeing.

Table 1: Determination of optimum concentration (Weight of sample (flowers) $=\mathrm{W}=10 \mathrm{~g}$; Volume of hot water taken $=\mathrm{V} \mathrm{ml}$; Concentration of the dye $(\mathrm{C})=$

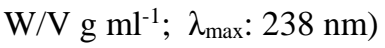

\begin{tabular}{|l|l|l|l|l|l|}
\hline $\mathbf{V}(\mathbf{m l})$ & $\mathbf{C}(\mathbf{1 0} / \mathbf{V})(\mathbf{g} / \mathbf{m l})$ & $\mathbf{D 1}$ & $\mathbf{D 2}$ & $\begin{array}{l}\text { D1 - } \\
\text { D2 }\end{array}$ & $\begin{array}{l}\text { A } \\
\text { Abs. }\end{array}$ \\
\hline 200 & 0.05 & 3.980 & 2.341 & 1.639 & 41.181 \\
\hline $\mathbf{4 0 0}$ & $\mathbf{0 . 0 3}$ & $\mathbf{3 . 3 1 1}$ & $\mathbf{1 . 6 4 3}$ & $\mathbf{1 . 6 6 8}$ & $\mathbf{5 0 . 3 7 7}$ \\
\hline 600 & 0.02 & 3.931 & 2.729 & 1.202 & 30.577 \\
\hline
\end{tabular}

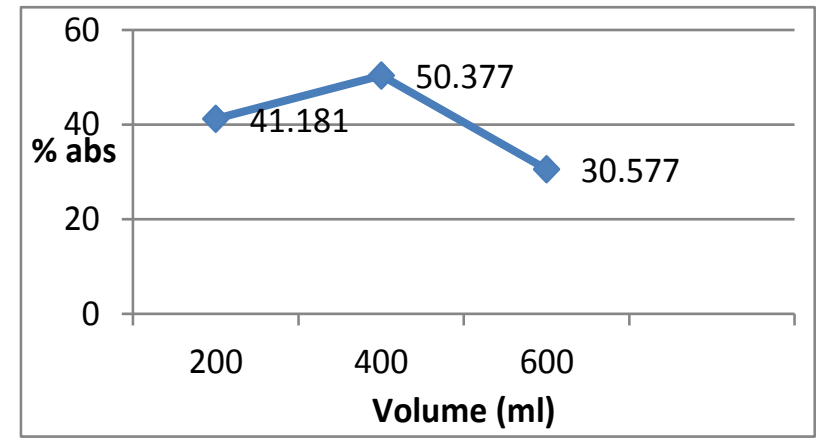

Figure 2: Volume vs \% absorbance

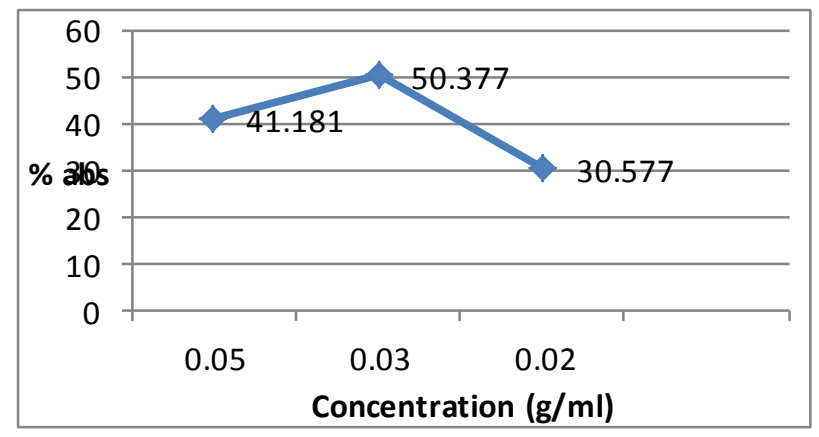

Figure 3: Concentration vs \% absorbance

Table 2: Determination of optimum time $\lambda_{\max }=$ $238 \mathrm{~nm}$

\begin{tabular}{|l|l|l|l|l|}
\hline Time(min) & D1 & D2 & D1-D2 & \% Abs. \\
\hline 15 & 0.649 & 0.843 & -0.194 & -29.890 \\
\hline $\mathbf{3 0}$ & $\mathbf{3 . 3 1 1}$ & $\mathbf{1 . 6 4 3}$ & $\mathbf{1 . 6 6 8}$ & $\mathbf{5 0 . 3 7 7}$ \\
\hline 45 & 3.215 & 2.642 & 0.573 & 17.820 \\
\hline 60 & 2.482 & 1.689 & 0.793 & 31.950 \\
\hline
\end{tabular}




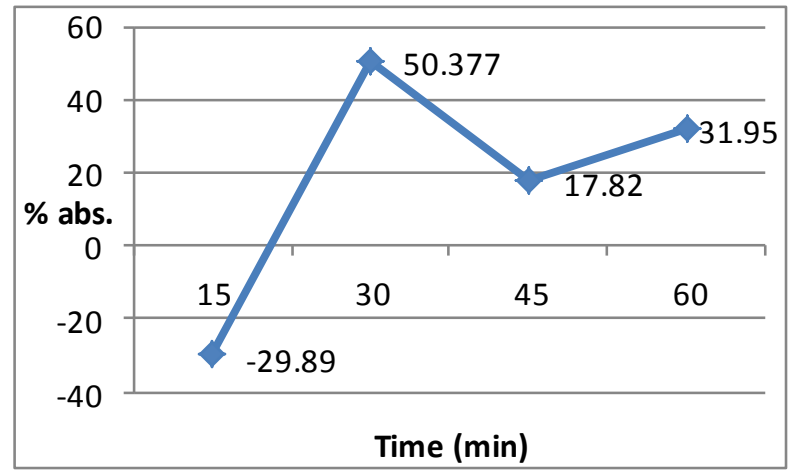

Figure 4: Time vs \% absorbance

Table 3: Mordanting of wool with S. racemosa leaves (Fibre: Wool Dye: R.arboreum flowers Mordant: S. racemosa leaves $\lambda_{\max }=416 \mathrm{~nm}$ )

\begin{tabular}{|l|l|l|l|l|l|}
\hline $\begin{array}{l}\text { Type of } \\
\text { Mordanting }\end{array}$ & D1 & D2 & $\begin{array}{l}\text { D1- } \\
\text { D2 }\end{array}$ & $\begin{array}{l}\text { \% } \\
\text { Abs. }\end{array}$ & $\begin{array}{l}\text { Shade } \\
\text { obtained }\end{array}$ \\
\hline Pre & 3.612 & 2.642 & 0.97 & 26.85 & $\begin{array}{l}\text { Light } \\
\text { yellow }\end{array}$ \\
\hline Post & 3.612 & 2.341 & 1.271 & 35.19 & $\begin{array}{l}\text { Pale } \\
\text { yellow }\end{array}$ \\
\hline Simultaneous & 3.612 & 1.689 & 1.923 & 53.24 & $\begin{array}{l}\text { Dark } \\
\text { yellow }\end{array}$ \\
\hline
\end{tabular}

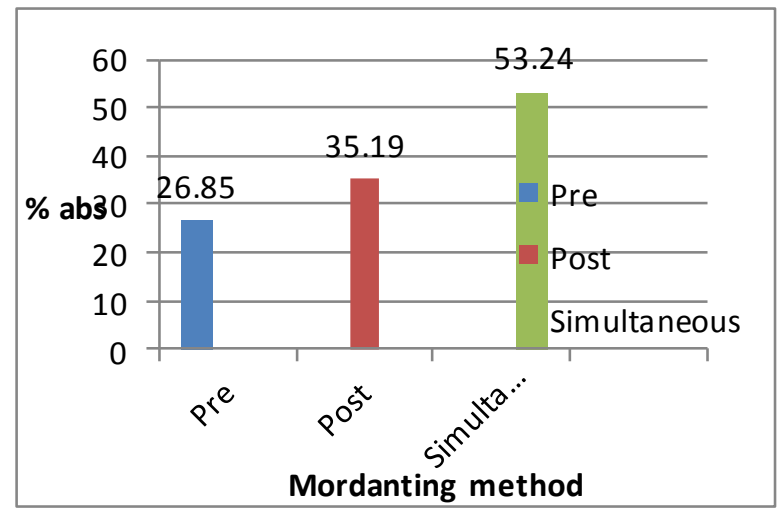

Figure 5: Mordanting method vs \% absorbance

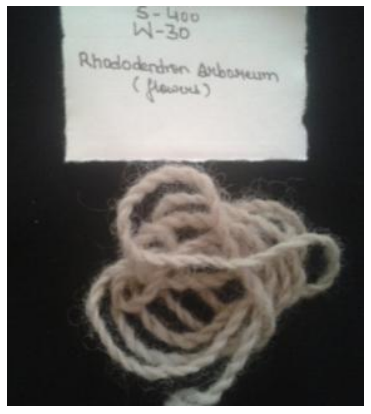

(a) Creamish pink

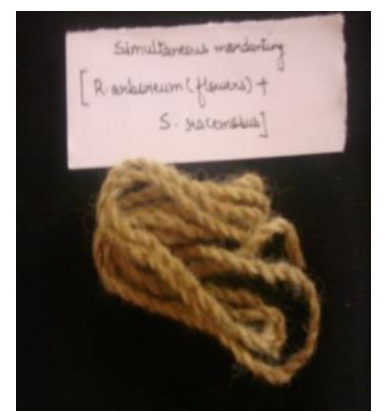

(b) Dark yellow
Figure 6: Image of extracted dyes (a-b): $R$. arboreum flowers $(400 \mathrm{ml}, 30 \mathrm{~min})$ (a); R. arboreum (flowers)+S. racemosa (leaves): Simultaneous mordanting (b).

\section{Results and discussion}

The wool sample corresponding to volume of 400 $\mathrm{ml}$ gave maximum percentage absorbance (Table 1) implying that the optimum concentration of $R$. arboreum flowers for dyeing wool is $10 \mathrm{~g}$ per 400 $\mathrm{ml}$ hot water. Table 2 makes it clear that the sample corresponding to 30 minutes showed maximum percentage absorbance. Thus, for dyeing wool $10 \mathrm{~g}$ of flowers per $400 \mathrm{ml}$ hot water extracted for 30 minutes gave the best result.

The simultaneous mordanting method (Fig. 6) showed the best result when wool was mordanted with S. racemosa leaves (Table 3).

Therefore, in accordance with the maximum values of $\%$ absorbance in tables 1,2 and 3 it is clear that:

- Optimum concentration $=10 \mathrm{~g} R$. arboreum flowers in $400 \mathrm{ml}$ hot water $=$

$0.03 \mathrm{~g} \mathrm{ml}^{-1}$

- Optimum time for dyeing $=30 \mathrm{~min}$

- Optimum mordanting method $=$ Simultaneous mordanting

The woolen fibre dyed with $R$. arboretum flowers only was creamish pink in colour while dark yellow shade was obtained when wool dyed with $\mathrm{R}$. arobreum flowers was mordanted simultaneously with S. racemosa leaves. Thus, we see that R. arboreum flowers on their own are good sources of natural dyes and using them in combination with $\mathrm{S}$. racemosa leaves as natural mordant further produces different shades.

The excellent dye ability exhibited by woolen fiber is attributed to its high values of polarity (2.1) and porosity (Joshi et al., 2013).This is because the dye ability increases with the increase of porosity (Rekaby et al., 2009; Selvam et al., 2015; Houet al., 2013). Also the hygroscopic nature of wool fabric makes it absorb more water due to the presence of several amorphous regions in its molecular chains leading to the swelling of the fibre, thereby increasing the diffusion of the dye solution considerably (Cristea and Vilarem 2016; Mohamedet al., 2015; Uddin, 2015). Another reason for the excellent dye ability shown by wool is that the wool molecules are present in the form of flexible chain and bind together with 
natural cross-linkages and salt bridges that help the attraction of more dye molecules to the vicinity of the fiber micelles, hence, increasing the dye ability (Lewis, 1992; Gies et al., 2017).

\section{Conclusion}

The present investigation was planned in search of environmentally benign alternative to the synthetic dyes and mordants, which has been made with the use of Rhododendron arboretum flowers as dye and Symplocos racemosa leaves as mordant. It was shown that colour yields were found to be enhanced by the addition of mordant at an optimum concentration. Thus, the method used for dyeing the fiber using natural dye and natural mordant instead of synthetic dye and mordant proves to be advantageous as this method uses minimum raw material, water as a solvent which can be reusable in multiple dyeing session and is less toxic, cost effective and ecofriendly. Thus, it proves to be a safe option for the cause of saving environment. Using various parts of plants as source of natural dyes and natural mordants will certainly pave a way in this direction.

\section{Conflict of interest}

The authors declare that there is no conflict of interests regarding the publication of this article.

\section{References}

Antima S, Dangwal LR, Dangwal M (2012) Dye yielding plants of the Garhwal Himalaya, India: a case study. International Research J. Biolo. Sci.1 (4):69-72.

Atkinson ET (1882) Gazetteer of the Himalayan districts of the NW Provinces of India. Allahabad.

Chauhan NS (1999) Medicinal and aromatic plants of Himachal Pradesh. Indus publishing, New Delhi.

Cristea D,Vilarem G (2006) Improving light fastness of natural dyes on cotton yarn. Dyes pigm.s. 70(3):238-245.
Gaur RD. 1999. Flora of the District Garhwal, North West Himalaya. Transmedia.

Gaur RD (2008) Traditional dye-yielding plants of Uttarakhand, India, Nat.Prod. Radi. 7(2):154165.

Geetha B, Sumathy VJH (2013) Extraction of Natural Dyes from Plants. International $J$. Chem. Pharma. Sci. 1(8):502-509.

Gies P, Elix R, Lawry D, Gardner J, Hancock T, Cockerell S, Roy C, Javorniczky J, Henderson S (2017) Assessment of the UVR protection provided by different tree species. Photo. Photobiol. 83(6):1465-1470.

Gulrajani ML (1999) Natural dyes-Part I: Present status of natural dyes. Colourage.; 46:19-28.

Gulrajani ML (2001) Present status of natural dyes. Indian J. Fib.Text. Res.. 26:191-201.

Gulrajani ML, Bhaumik S, Oppermann W,Hardtmann G (2003)Dyeing of red sandal wood on wool and nylon. Indian J. Fib.Text. Res. 28(2):221-226.

Gulrajani ML, Deepti G (2011) Emerging techniques for functional finishing of textiles. Indian J. Fib.Text. Res. 36:388-397.

Han S, Yang Y (2005) Antimicrobial activity of wool fabric treated with curcumin. Dyes and pigments 64(2):157-161.

Hou X, Chen X, Cheng Y, Xu H, Chen L, Yang Y (2013) Dyeing and UV-protection properties of water extracts from orange peel. J. Cleaner Prod. 52:410-419.

Joshi RK, Purohit MC, Joshi SP (2013) Improvement of the traditional system of 'dyeing on wool fibers using eco-friendly natural dye. J. Appl. Chem. 2(4):841-849.

Khan SA, Ahmad A, Khan MI, Yusuf M, Shahid M, Manzoor N, Mohammad, F (2012) Antimicrobial activity of wool yarn dyed with Rheum emodi L. (Indian Rhubarb). Dyes Pigm.. 95(2):206-214.

Kundal Jyoti, Purohit Pranjali, Joshi R.K and Purohit M.C. (2014) Optimmization of procedure for dyeing cotton and wool fabric with natural dye extracted from Myrica esculanta, using different mordant, $J$. Mountain Res.9: 101-110 
Laloo RC, Kharlukhi L, Jeeva S, Mishra BP (2006) Status of medicinal plants in the disturbed and the undisturbed sacred forests of Meghalaya, northeast India: population structure and regeneration efficacy of some important species. Curr. Sci. 90(2):225-232.

Lewis DM (1992) Wool dyeing. Society of Dyers and Colourists, Bradford, West Yorkshire.

Mohamed FA, Ali NF, El-Mohamedy RSR (2015) The dye ability and antimicrobial activity of wool fibers dyed with reactive dyes and pretreated with chitosan. Int. J. Curr. Micro. Appl. Sci. 4(11):587-596.

Mukherji A (1999) Dyeing of cotton fabric with KigeliaPinnata, SpathodeaCompanulata and Carissa Congesta. In Book of papers of the convention on natural dyes. Department of Textile Technology, IIT Delhi, New Delhi.

Naz S, Bhatti IA (2011) Dyeing properties of cotton fabric using un-irradiated and gamma irradiated extracts of Eucalyptus camaldulensis bark powder. Indian $J$. Fib.Text. Res. 36(2):132-146.

Negi GS (2006) History of the origin of Shauka Tribe of Middle Himalayas. Lucknow J. Soci. Sci. (3)2: 9-15

Pradhan UC, Lachungpa ST (1990) SikkimHimalayan Rhododendrons. Primulaceae Books.

Purohit P, Kundal J, Purohit, MC (2015) Optimization of procedure for dyeing of cotton fibers with Rhododendron arboretumf lowers using Symplocos racemosa leaves as mordants, J. Appl. Chem. 4(6):1852-1857.

Purohit P, Purohit MC, Sati SC (2008) Optimization of Procedure for Dyeing of Wool and Cotton Fibres with Rhododendron arboretum - A Source of Eco-friendly Natural Dyes. Asian J. Chem. Envi. Res. 1(1):13-17.

Purohit Pranjali and Purohit M.C. (2018). Use of Rhus Parviflora leaves as natural dyes: Determination of optimum dyeing conditions and assessment of washing fastness on woolen sample in absence and presence of natural mordant (Symplocos racemosa leaves) $J$ Mountain Res.13: 69-74
Rekaby M, Salem AA, Nassar SH (2009) Ecofriendly printing of natural fabrics using natural dyes from alkanet and rhubarb. $J$ Text. Inst. 100(6):486-495.

Samanta AK, Agarwal P (2007) Dyeing of jute and cotton fabrics using Jackfruit wood extract: Part I-Effects of mordanting and dyeing process variables on colour yield and colour fastness properties. Indian J. Fib.Text. Res. 32(4):466-476.

Selvam RM, Athinarayanan G, Nanthini AUR, Singh AR, Kalirajan K, Selvakumar PM (2015) Extraction of natural dyes from Curcuma longa, Trigonella foenumgraecum and Nerium oleander, plants and their application in antimicrobial fabric. Indust. Crops Prod.70:84-90.

Singh AR, Kalirajan K (2012) Anti-microbial Activity of Turmeric Natural Dyeagainst Different Bacterial Strains. J. Appl. Pharm. Sci. 2(6):210-212.

Singh Shyaveer, Purohit M.C (2014) Evaluation of colour fastness properties of natural dye extracted from Symplocos racemosa (Lodh) on wool fibres using combination of natural and synthetic mordants. Indian J. Fib.Text. Res. 39:97-101.

Uddin MG (2015) Extraction of eco-friendly natural dyes from mango leaves and their application on silk fabric. Text. Clot. Sustain. 1(1):7. 